\title{
KONCEPCJE RYZYKA W BADANIU STOSUNKÓW MIĘDZYNARODOWYCH ${ }^{1}$
}

\author{
Anna Moraczewska \\ Uniwersytet Marii Curie-Skłodowskiej w Lublinie \\ Wydział Politologii, Zakład Stosunków Międzynarodowych \\ adres, e-mail: anna.moraczewska@poczta.umcs.lublin.pl
}

\begin{abstract}
Streszczenie. Tematem artykułu jest ryzyko, traktowane jako kategoria badawcza - z szeroko opracowaną bazą metodologiczną i możliwością jej zastosowania w analizie współczesnych stosunków międzynarodowych. Przedstawione zostały propozycje definicji wypracowane przez różnych znawców „ryzyka” oraz wyniki raportów wybranych organizacji, które po pierwsze coraz powszechniej stosują analizy ryzyka w swoich opracowaniach i po drugie są źródłem istotnych informacji służących budowaniu strategii bezpieczeństwa międzynarodowego. Celem artykułu jest zwiększenie zainteresowania naukowców zastosowaniem kategorii ryzyka do badań w stosunkach międzynarodowych.
\end{abstract}

Słowa kluczowe: ryzyko, koncepcje ryzyka, rodzaje ryzyka, raporty o ryzyku, współpraca państw w dziedzinie zarządzania ryzykiem

\section{WSTĘP}

Ryzyko, jego analiza i zarządzanie nim stały się istotną kategorią badawczą społeczeństwa post-modernistycznego. Znaczący wkład w rozwój studiów nad ryzykiem w naukach społecznych miały prace Ulricha Becka'a, Anthona Giddensa, Franka Knighta, Marry Douglas, Scheily Jasanoff, a także Briana Wynne, choć liczba badaczy tego zjawiska jest znacznie większa. W nauce o stosunkach międzynarodowych badania ryzyka nie są zbytnio popularne. W swej genezie toczyły się debaty między podejściami krytycznego realizmu, konstruktywizmu i post-strukturalizmu. Ich głównym tematem było ontologiczne pytanie o istnienie ryzyka lub jego nieistnienie oraz epistemologiczny dylemat jego obiektywizmu.

1 Artykuł powstał w ramach realizacji grantu badawczego finansowego przez Narodowe Centrum Nauki, Nr 2011/03/D/HS5/02 501. 
Ryzyko jest związane z niepewnością, która stanowi punkt wyjścia do jego analizy. Wzrost złożoności współczesnych stosunków międzynarodowych poprzez zwiększenie liczby i rodzajów podmiotów, a tym samym interakcji między nimi, wpływają na wzrost ich skomplikowania i zależności i większą niepewność co do przyszłości. Jednocześnie podniesienie poziomu świadomości istnienia ryzyka oraz możliwości gromadzenia i przetwarzania informacji wpłynęły na rozwój modeli redukowania owej niepewności do poziomu kontrolowanego, w jakimś stopniu, ryzyka.

Analiza ryzyka w uproszczonym ujęciu dotyczy zbadania prawdopodobieństwa wystąpienia pewnego zjawiska oraz ustalenia jego konsekwencji. Jest związana z pojęciem szeroko rozumianego bezpieczeństwa i ma na celu określenie determinantów i wielkości prawdopodobnych strat oraz sposobów ich eliminowania. Większość analiz nad ryzykiem w dziedzinie stosunków międzynarodowych koncentruje się wokół skutków globalizacji (globalization of fear), terroryzmu i ekologii. Naukowe analizy ryzyka mają również swoje zastosowanie $\mathrm{w}$ badaniach nad wykorzystaniem nowych technologii, GMO, tworzeniem systemów zabezpieczających państwowe sieci informacyjne przed cyberterroryzmem i hakerstwem, ryzykiem epidemiologicznym czy ryzykiem wynikającym z wyczerpywania się zasobów naturalnych. Istotnymi kwestiami, jednak rzadziej podejmowanymi w analizach ryzyka, są np. identyfikacja słabych miejsc w państwach narażających je na destabilizację lub stanowiących źródło zagrożenia ${ }^{2}$, czy też wpływ organizacji międzynarodowych w regulowaniu ryzyka między państwami np. przy nadmiernym zadłużenia państw na rynku finansowym. Zastosowanie tej metody badawczej ułatwia identyfikację przyczyn zjawiska tzw. państw upadłych (failed states) i budowanie modeli decyzyjnych zabezpieczających przed nim lub łagodzących jego skutki.

Kwestią wymagającą badań jest określenie istoty ryzyka i metod zarządzania nim, które kształtują decyzje na poziomie państwowym i międzynarodowym. Coraz więcej organizacji międzynarodowych wykorzystuje wybrane modele analizy ryzyka w zakresie swojej działalności, MFW - pożyczek, WTO - umów handlowych, ONZ - akcji pomocowych, a także są one elementem umów bilateralnych i multilateralnych między państwami np. w dziedzinie środków sanitarnych i fitosanitarnych dotyczących przewozu towarów przez granice, czy udostępniania list pasażerów samolotów między państwami ze względu na zagrożenia terrorystyczne. Zostały również wypracowane międzynarodowe standardy zarządzania ryzykiem, które są wykorzystywane przez podmioty w różnych płaszczyznach stosunków międzynarodowych.

2 Te kwestie dużo częściej znajdują się w sferze tzw. zarządzania kryzysowego na poziomie państwa i obejmują m.in. powoływanie stałych lub tymczasowych jednostek zajmujących się zarządzaniem kryzysowym wobec określonego zdarzenia poprzez zapobieganie, przejmowanie kontroli nad nim, usuwanie skutków. Nie jest ono tożsame z pojęciem zarządzania ryzykiem, choć wydaje się, że wspomniane zjawiska wychodzą poza granice państwa i są uwarunkowane również czynnikami zewnętrznymi (np. kryzys finansowy na świecie, wzrost lub spadek cen ropy naftowej) i tym samym wymagają bardziej złożonych mechanizmów prewencyjnych. 
O ile jednak w działaniach aktorów stosunków międzynarodowych możemy znaleźć strategie wykorzystujące mechanizmy analizy i zarządzania ryzykiem, o tyle rzadko stosowane są one jako metoda badawcza współczesnych stosunków międzynarodowych. Biorąc pod uwagę dość szeroko wypracowane metody analizy ryzyka w takich dziedzinach jak ekonomia czy bezpieczeństwo, wydaje się, że stanowią one również cenny instrument badawczy stosunków międzynarodowych. Stąd celem niniejszego artykułu jest ukazanie istoty ryzyka w tej dziedzinie wiedzy i wskazanie płaszczyzn analizy ryzyka, które już stały się przedmiotem debat na poziomie międzynarodowym.

\section{KONCEPCJE DOTYCZĄCE RYZYKA}

Ze względu na heterogeniczną istotę ryzyka, sformułowano kilkanaście definicji tego pojęcia. Może być ono badane w różnych kontekstach, jako niebezpieczeństwo, prawdopodobne zagrożenie, czy niepewność, czasem również w kategoriach pozytywnych - jako szansa osiągnięcia zysku. ${ }^{3}$ Częściej jednak ujmowane jest jako strata będąca konsekwencją wystąpienia zjawiska o cechach negatywnych (pożaru, trzęsienia ziemi, ataku terrorystycznego) lub jako prawdopodobieństwo braku osiągnięcia zamierzonego celu (np. zysków inwestycyjnych, poprawy stanu środowiska, obniżenia poziomu wody w czasie powodzi). Ryzyko nie powinno być jednak utożsamiane z pojęciem zagrożenia, ale jedynie możliwością jego zaistnienia.

Problemy definicyjne wynikają z różnych podejść w badaniu ryzyka, jako zjawiska istniejącego obiektywnie lub konstrukcji subiektywnej. Można stwierdzić, że trudno jest zachować obiektywizm w przewidywaniu przyszłości, która nie może być do końca poznana, szczególnie jeżeli istniej wiele zmiennych. Dlatego dwoma istotnymi elementami w analizowaniu ryzyka są niepewność i wiedza. Charles Yoe wyróżnia niepewność co do wiedzy i niepewność pochodzenia naturalnego. Pierwsza z nich może zostać zredukowana dzięki badaniom, zbieraniu i analizowaniu danych, tworzeniu lepszych modeli analitycznych, uzupełnianiu braków w informacjach, ciągłym uaktualnianiu ich i poprawie błędnych założeń. Natomiast niepewność pochodzenia naturalnego jest niepewnością losową, stochastyczną i nie może być zredukowana w wyniku gromadzenia i optymalizowania analizy informacji. ${ }^{4}$ Tadeusz Kaczmarek twierdzi jednak, że w odniesieniu do tzw. ubezpieczonego ryzyka, wywodzącego się z teorii ubezpieczeń, zjawiska niepewności mogą być kwantyfikowane w oparciu o statystyczne prawdopo-

3 W przypadku oczekiwania jakichś korzyści, np. na rynku finansowym, mamy do czynienia z tzw. ryzykiem spekulacyjnym, gdzie istniej określony stopień niepewności uzyskania zysków.

${ }^{4}$ Ch. Yoe, Principles of Risk Analysis: Decision Making Under Uncertainty, Boca Raton 2012, CRC Press, s. 29 
dobieństwo zaistnienia niebezpieczeństwa. ${ }^{5}$ Zachodzi więc sprzężenie między niepewnością i wiedzą polegające na tym, że rozwój wiedzy, w tym metod badawczych, analiz danych, schematów działań wpływa na lepsze poznanie sytuacji niepewnych i pozwala na ich kształtowanie.

Z drugiej strony w analizie ryzyka wykorzystywane są dane statystyczne, jak np. częstotliwość występowania danego zjawiska, ocena strat i ich wpływu czy siły sprawcze. Ryzyko jest wówczas traktowane jako jednostka mierzalna której znaczenie można ocenić na podstawie formalnej logiki indukcyjnej. Stosowany jest rachunek prawdopodobieństwa i wiele wzorów matematycznych na jego obliczenie. Najprostszą metodą zbadania ryzyka jest obliczenie iloczynu prawdopodobieństwa i skutków wystąpienia niebezpieczeństwa. Poszczególnym parametrom przypisywane są wartości liczbowe. Takie podejście najłatwiej znaleźć w naukach ekonomicznych, gdzie ocena ryzyka jest podstawą podejmowania niemal każdej działalności na rynku. Ponadto ma swoje zastosowanie np. w mierzeniu strat materialnych będących wynikiem katastrof naturalnych. Ryzyko można więc określić jako miarę prawdopodobieństwa wystąpienia skutków przyszłych wydarzeń. Poziom niepewności wzrasta, gdy wiedza na temat danego zjawiska jest mała, a liczba informacji ograniczona. W takiej sytuacji zastosowanie sprawdzonych czy znanych modeli działania nie zawsze przynosi oczekiwane efekty.

Istotą ryzyka jest odniesienie go do skutków, jakie może wywołać pewne zjawisko czy wydarzenie. Ch. Yoe podaje dwa rodzaje źródeł ryzyka: pochodzenia naturalnego i będące wynikiem działalności człowieka Obydwa, mimo różnej siły sprawczej pociągają za sobą podobne skutki. I tak np. trzęsienia ziemi, huragany, czy burze, w odniesieniu do jednostki ludzkiej, powodują ryzyko utraty życia, majątku, zdrowia itp. Analogicznie produkcja i użycie broni, technologii, środków chemicznych, emisja i sprzedaż 'toksycznych' papierów wartościowych i in. skutkują podobnymi stratami. W przypadku tych drugich należy jednak wkalkulować dodatkowo m.in. zniszczenie równowagi ekosystemu, wystąpienie kryzysu gospodarczego, wzrost niepokojów w jakimś regionie ${ }^{6}$, łamanie praw człowieka czy chaos polityczny i społeczny. Oznacza to, że negatywne skutki działalności ludzkiej mają dużo szerszy zasięg i często głębsze konsekwencje negatywne dla stabilności środowiska międzynarodowego niż wynikające z ryzyka pochodzenia naturalnego. ${ }^{7}$

$\mathrm{W}$ definiowaniu zjawiska ryzyka istotne znaczenie ma płaszczyzna jakiej ono dotyczy oraz podmiot, które je określa. Wtedy zazwyczaj jest ono zawężone i/lub bardziej specjalistyczne. Występują np. w dziedzinie ekonomii - ryzyko kredy-

5 T. Kaczmarek, Ryzyko i zarządzanie ryzykiem. Ujęcie interdyscyplinarne, Warszawa 2006, s. 54.

${ }^{6}$ Ch. Yoe, Principles of Risk Analysis: Decision Making Under Uncertainty, Boca Raton 2012, CRC Press, s. 3.

7 Istniej jednak dylemat związany ze zjawiskiem ocieplania klimatu, gdzie przyjmuje się, że działalność człowieka zmienia funkcjonowanie warunków naturalnych, a te przynoszą zjawiska, takie jak powodzie, susze, huragany, trąby powietrzne $\mathrm{i}$ in, stanowiące poważne zagrożenie dla egzystencji człowieka. 
towe, inwestycyjne, kursowe czy stopy procentowej, w medycynie, biologii czy chemii - ryzyko epidemiologiczne, zakażenia, zachorowania, toksykologiczne; w dziedzinie ekologii - ryzyko skażenia środowiska, utraty bioróżnorodność, zachwiania równowagi ekosystemu, wyczerpania zasobów naturalnych, w naukach politycznych - ryzyko terrorystyczne, ryzyko wystąpienia kryzysu rządowego lub ryzyko wybuchu konfliktu czy wojny. W wielu przypadkach wykorzystuje się podobne teoretyczne modele analizowania ryzyka i zarządzania nim, jednak jego heterogeniczność i zmienność natury nakazują stałe wypracowywanie nowych sposobów jego oceny i uwzględnienie specyficznych cech zjawiska oraz zakresu wiedzy w danej dziedzinie.

\section{BADANIA NAD RYZYKIEM W STOSUNKACH MIĘDZYNARODOWYCH}

W stosunkach międzynarodowych badania dotyczące kwestii ryzyka toczyły się w ramach debaty między podejściami krytycznego realizmu, konstruktywizmu i post-strukturalizmu. Ich głównym tematem było ontologiczne pytanie o istnienie ryzyka lub jego nieistnienie. Według krytycznego realizmu ryzyko jest obiektywne i istnieje w rzeczywistości i obie zmienne wzajemnie się konstytuują. Konstruktywiści uważają, że ryzyko nie stanowi zobiektywizowanej sytuacji, która istnieje niezależnie od podmiotów oceniających ryzyko i jest konstrukcją społeczną zależną od norm i intersubiektywnego poznania. Post-strukturaliści postrzegają ryzyko przez pryzmat pewności sądów o rzeczywistości. Uważają, że ryzyko nie jest rzeczywiste i jest tylko sztuczną konstrukcją opartą na wyliczeniach i racjonalizowaniu rzeczywistości opisującej problemy społeczne w kategoriach ryzyka, a w efekcie techniką rządzenia i kontrolowania ludzi. ${ }^{8} \mathrm{U}$. Beck połączył w swoim podejściu do ryzyka kilka powyższych koncepcji pisząc, że ryzyko jest jednocześnie obiektywną rzeczywistością i konstrukcją społeczną przyjmując tym samym ontologię realistów i epistemologię konstruktywistów. ${ }^{9}$ Dla Becka główną przyczyna pojawiania się, określonego przez niego, ,,społeczeństwa ryzyka” jest postępujący rozwój industrializacji i postęp technologiczny prowadzące do modernizacji społeczeństwa oraz określone decyzje międzynarodowe podejmowane w różnych ośrodkach decyzyjnych. Te ostatnie mogą definiować co jest ryzykiem, a co nie jest dla danych grup społecznych. Stąd podejście Becka łączy elementy istniejące obiektywnie z subiektywnym postrzeganiem zjawisk. Jednocześnie zaznacza on wyraźne różnice między pojęciami ryzyka i niebezpieczeństwa, z których pierwsze jest wynikiem działania człowieka, a drugie pochodzenia natural-

8 W. Clapton, Risk in International Relations, "International Relations" vol. $25 \mathrm{nr} 3$, SAGE 2011, s. 280-281.

9 Szerzej: U. Beck, Risk Society Revised: theory, Politics and Research Programme, [w:] The Risk Society and Beyond: Critical Issues for Social Theories, (red.) B. Adam, u. Beck, J. Van Loon, Londyn 200, s. 211-229. 
nego. O ile więc zagrożenia są realne to ich skutki są trudne, a często niemożliwe do przewidzenia. ${ }^{10} \mathrm{~W}$ swoich kolejnych pracach, wraz z Anthony Giddensem i Scottem Lashem, więcej miejsca poświęca niepewności, która pojawia się wraz z postępem technologicznym i nieprzewidywalnością skutków tego procesu. ${ }^{11}$

Nieco inne podejście reprezentował ekonomista Frank Knight koncentrując swoje badania wokół trzech pojęć: ryzyka, niepewności i prawdopodobieństwa. Odnosił je do możliwości i sposobów przewidywania przyszłych wydarzeń przez aktorów społecznych oraz ich wpływu na wyniki. Dylemat, wokół którego tworzył teorię i metody analizy tych pojęć, dotyczył kwestii na ile człowiek racjonalny może działać racjonalnie opierając swoje rozważania na rzeczywistości, która nie może zostać poznana do końca, czy też zjawiskach, które jeszcze nie istnieją. Wskazywał on na istnienie ograniczeń posiadanej wiedzy pozwalającej na przewidywanie i rozumienie ludzkich zachowań. Stąd Knight podkreślał różnice między pojęciami ryzyka i niepewności, z których pierwsze oparte jest na obiektywnie istniejących zjawiskach, których częstotliwość, znaczenie, dotkliwość czy konsekwencje mogą być rzeczowo ocenione i są mierzalne, natomiast zjawisko niepewności dotyczy braku wiedzy lub informacji o danym zjawisku i nie da się określić jego liczbowych parametrów. ${ }^{12}$ Obliczenie poziomu prawdopodobieństwa zaistnienia jakiegoś zjawiska czy wydarzenia daje możliwości wypracowania metod zarządzania ryzykiem, ale także przewidzenia ich konsekwencji. Biorąc pod uwagę okres twórczości Knighta - przełom połowy XX w., uwarunkowania środowiska międzynarodowego odbiegały znacząco od obecnych. Funkcjonowanie systemu bipolarnego, mniejsza liczba aktorów oraz niższy poziom współzależności dawały większe możliwości przewidywania działań podmiotów stosunków międzynarodowych. Obecny wzrost niepewności, a także, paradoksalnie, wiedzy komplikują badania nad kategorią ryzyka w stosunkach międzynarodowych, ale również przyczyniają się do tworzenia coraz nowych metod radzenia sobie z problemami. W odniesieniu do koncepcji „społeczeństwa ryzyka” U. Becka, obecne zmiany społeczne, polityczne czy środowiska naturalnego są tak głębokie, że nie istnieje możliwość „opanowania” wszystkich źródeł ryzyka i optymalnego zarządzania nimi.

Antropolog - Mary Douglas część swoich badań poświęciła zjawisku ryzyka w relacji do kultury społecznej i reprezentowała w nich ujęcie społeczno-konstruktywistyczne. Pisała o tzw. kulturowej teorii ryzyka, według której postrzeganie ryzyka przez dane grupy społeczne ma kluczowe znaczenie $\mathrm{w}$ jego rozumieniu i jest ono determinowane przez obowiązujące normy i wartości kulturowe. Nie zaprzecza ona istnieniu rzeczywistych zagrożeń, jednak podkreśla, że to kultura odpowiada za ich postrzeganie, a ocena ryzyka związana jest z oczekiwaniami

${ }^{10}$ U. Beck, Spoleczeństwo ryzyka. W drodze do innej nowoczesności, Warszawa 2002, s.22-24.

${ }^{11}$ Szerzej: U. Beck, A. Giddens, S. Lash, Modernizacja refleksyjna: polityka, tradycja i estetyka w porzadku społecznym nowoczesności, Warszawa 2009.

${ }_{12}$ D. S. L. Jarvis, Theorising Risk and Uncertainty in International Relations: The Contributions of Frank Knight, "International Relations" vol. 25 nr 3, SAGE 2011, s. 298-299. 
wobec przyszłości. ${ }^{13}$ Stąd pewne zjawiska, których pojawienie uznawane jest za niebezpieczne dla funkcjonowania danej społeczności (np. brak elektryczności dla społeczeństw post-industrilanych) nie jest postrzegane jako ryzykowne dla normalnego funkcjonowania innych grup ludności.

Wzrost świadomości występowania ryzyka, a także umiejętności zarządzania nim przyczyniły się do zaadoptowania kategorii ryzyka w wypracowaniu strategii działań niektórych podmiotów stosunków międzynarodowych. Relatywnie najwcześniej rozwinęły to korporacje międzynarodowe ustalając kierunki swoich inwestycji na rynkach międzynarodowych pod względem ryzyka strat i szansy zysków, a następnie państwa i organizacje międzynarodowe realizujące cele swojej polityki. Mikkel Vedby Rasmussen twierdzi, że kategorie ryzyka i zarządzania nim stały się w XXI w. elementami wewnętrznej i międzynarodowej polityki bezpieczeństwa kilku zachodnich państw, a przede wszystkim Stanów Zjednoczonych. Dotyczy to również Unii Europejskiej czy NATO. Polityka oparta na koncepcji ryzyka dała początek działaniom uprzedzającym czy tzw. wojnom prewencyjnym. ${ }^{14}$ Przykładami są tu akcje w Kosowie, Afganistanie czy w Iraku z 2003 r. Europejską Politykę Sąsiedztwa można również traktować jako przykład miękkiej polityki bezpieczeństwa Unii Europejskiej (UE) z wykorzystaniem instrumentów zarządzania ryzykiem, polegającej na warunkowej pomocy finansowej dla państw sąsiednich Unii w zamian za wdrażanie mechanizmów demokracji i gospodarki liberalnej w tych państwach. Celem tych działań było zwiększenie przewidywalności ich zachowań w ramach znanych sobie (UE) zasad i własnego wpływu, a tym samym ograniczenie niepewności tych obszarów. ${ }^{15}$

Analiza ryzyka stanowi istotny element regulujący określone płaszczyzny współpracy między podmiotami stosunków międzynarodowych. Na przykład porozumienia WTO w sprawie barier technicznych w handlu (TBT) oraz środków sanitarnych i fitosanitarnych (SPS) wskazuje ocenę ryzyka jako pełnoprawny protekcyjny instrument regulacji handlu między państwami stosowany wobec zagrożenia zdrowia, życia i bezpieczeństwa obywateli suwerennego państwa. Podobnie dostęp do rynku w ramach ugrupowań integracyjnych, działania Światowej Organizacji Zdrowia czy Organizacji ds. Wyżywienia, a także wielu innych agend wyspecjalizowanych ONZ są oparte na analizie ryzyka wobec aktualnych problemów. Międzynarodowa Organizacja Normalizacji (Standaryzacji) określiła w jednym ze swoich dokumentów wytyczne dotyczące definiowani ryzyka i zarządzania, które zostały przyjęte przez wiele podmiotów gospodarczych i po-

${ }^{13}$ M. Douglas, Risk Acceptability According to Social Sciences, London 1986, s. 86; M. Douglas, Czystość i zmaza, Warszawa 2007, M. Douglas, risk and Blame, London 1992, s. 29.

${ }^{14}$ M. V. Rasmussen, the Risk Society at War: Terror, Technology and Strategy in the TwentyFirst Century, Cambridge 2006.

${ }^{15}$ Szerzej: A. Moraczewska, Wymiar wschodni Europejskiej Polityki Sąsiedztwa jako strategia zarządzania ryzykiem, „Przegląd Zachodni” nr 45/2014, s. 45-60. 
litycznych jako tzw. standard zarządzania ryzykiem, (ISO 31000 oraz „Zalecenie ISO/IEC nr 73"). ${ }^{16}$

Wypracowana na gruncie naukowym - głównie matematyki i ekonomii, metodologia analizy i zarządzania ryzykiem znalazła swoje praktyczne zastosowanie w działaniach różnych podmiotów stosunków międzynarodowych. Stanowi instrument w badaniach i tworzeniu raportów dotyczących współczesnych zagrożeń w środowisku. Analiza ryzyka jest coraz częściej stosowana przez organizacje międzynarodowe $\mathrm{w}$ regulacjach porozumień między ich członkami oraz jako miernik prawdopodobnych zagrożeń, na jakie może być narażone zaangażowanie tych organizacji w państwach czy regionach lub jakiego rodzaju pomocy należy udzielić w celu zminimalizowania ryzyka.

\section{ANALIZY RYZYKA W ŚRODOWISKU MIĘDZYNARODOWYM}

Kategoria ryzyka nabrała istotnego znaczenia, kiedy uświadomiono sobie, że wiele zjawisk i skutków działalności człowieka wychodzi poza granice poszczególnych państw, a ich efekty nabierają cech ryzyka globalnego. Na początku XXI w. pojecie ryzyka stało się punktem odniesienia w analizach wielu zjawisk dla organizacji międzynarodowych takich jak Organizacja Narodów Zjednoczonych i jej wyspecjalizowane agendy, Organizacja Współpracy Gospodarczej i Rozwoju, Światowe Forum Ekonomiczne oraz na poziomie poszczególnych państw. Sporządzana przez nich analiza ryzyka uwzględnia najczęściej zjawiska zgodne z głównym profilem działalności tych podmiotów.

W grudniu 1999 r. ustanowiono Międzynarodowe Biuro Narodów Zjednoczonych ds. Redukcji Katastrof (United Nations Office for Disaster Risk Reduction - UNISDR) mające formę stałego sekretariatu w strukturze ONZ. W 2008 r. powołano Sekretarza ds. Redukcji Ryzyka Katastrof, który reprezentuje Sekretarza Generalnego w sprawach związanych z katastrofami naturalnymi na świecie. Celem UNISDR jest włączanie koncepcji Strategii Redukcji Ryzyka Katastrof w politykę zrównoważonego rozwoju państw członkowskich, rozwijanie i wzmacnianie mechanizmów i instytucji ograniczających i zarządzających skutkami katastrof czy zmniejszających ryzyko ich występowania. Na poziomie centralnym zajmuje się prowadzeniem dyskusji między-agencyjnych i poszczególnych państw prowadząc współpracę z regionalnymi komisjami ONZ, a w szczególności z Komisją Gospodarczo Społeczną dla Azji i Pacyfiku oraz Komisją Gospodarczą dla Ameryki Łacińskiej i Karaibów. ${ }^{17}$ Zakres działań w ramach strategii Redukcji Ryzyka Katastrof obejmuje ograniczanie szkód spowodowanych przez zagrożenia natu-

${ }^{16}$ Norma ISO 3100:2009, <https://www.iso.org/obp/ui/\#iso:std:iso:31000:ed-1:v1:en>, (16.08.2015)

${ }_{17}$ The United Nations Office for Disaster Risk Reduction, <http://www.unisdr.org/who-weare/unisdr-in-un>, dostęp online (12.07.2015). 
ralne takie jak trzęsienia ziemi, powodzie, susze i cyklony. Istotnym celem jest uzyskiwanie porównywalnych wskaźników ryzyka katastrof dla poszczególnych krajów i podnoszenie świadomości ich występowania na poziomie narodowym i międzynarodowym.

Podczas trzeciej światowej konferencji ONZ, która odbyła się w marcu 2015 r. w Sendai w Japonii opracowano Ramy Koncepcyjne z Sendai dla Redukcji Ryzyka Katastrof na lata 2015-2030 (The Sendai Framework for Disaster Risk Reduction 2015-2030). ${ }^{18}$ Zmiany klimatyczne uznano za jeden z najważniejszych czynników generujących ryzyko wystąpienia katastrof. We wcześniejszym programie, z 2013 r., określono agendy i komisje regionalne oraz organy stałe ONZ, których działania na rzecz redukcji ryzyka katastrof uznano za kluczowe. Wśród nich są m.in. Organizacja ds. Rolnictwa i Wyżywienia, Międzynarodowa Organizacja Pracy, Międzynarodowa Organizacja ds. Migracji, Międzynarodowa Organizacja Morska, Międzynarodowa Unia Telekomunikacyjna, Organizacja NZ ds. Oświaty, Nauki i Kultury, Fundusz NZ ds. Ludnościowych, Fundusz NZ na rzecz Dzieci, Światowy Program Żywnościowy, Światowa Organizacja Zdrowia, Bank Światowy, Światowa Organizacja Meteorologiczna, Program NZ ds. Środowiska, Komisja Gospodarcza NZ ds. Europy, Komisja Gospodarcza NZ ds. Afryki, Komisja Ekonomiczna NZ dla Ameryki Łacińskiej i Karaibów, Komisja Ekonomiczna NZ dla Azji i Pacyfiku i in. ${ }^{19}$ Ponadto dwanaście organizacji ONZ --FAO, UNDP, UNEP, UNFPA, UNHABITAT, UNICEF, UNOPS, WFP WMO, WHO, UNESCO i Bank Światowy uznały za priorytetowe w swoich planach strategicznych na lata 2014-2017 ograniczenie ryzyka katastrof. Współpraca poszczególnych podmiotów między sobą oraz z państwami na poziomie regionów, centralnym i lokalnym, a także koordynacja ich działań w zarządzaniu ryzykiem występowania katastrof pochodzenia naturalnego, ujawnia istotę kategorii ryzyka w kształtowaniu nowych interakcji między aktorami stosunków międzynarodowych. Uruchamia także nowe procesy decyzyjne na poziomie międzynarodowym, których wymiernym efektem są decyzje dotyczące przywracania równowagi środowiska naturalnego i programy pomocowe redukujące ryzyko wystąpienia katastrof i/lub ich skutków. Włączenie większości wyspecjalizowanych agend ONZ w aktywność na rzecz zarządzania globalnym ryzykiem, może być postrzegane jako imperatyw skutecznego radzenia sobie z prawdopodobnymi zagrożeniami, które pojawiają się w wyniku tych katastrof i rozszerzają zakres swojego oddziaływania.

Szczególne miejsce zajmuje analiza ryzyka w raportach Programu NZ ds. Rozwoju (UNDP). W głównej mierze dotyczą one również katastrof naturalnych jednak w szerszej perspektywie. W roku 2011, UNDP zbadało związek między

${ }^{18}$ Nowe Ramy Koncepcyjne zastąpiły wcześniejszy program - Ramy Działania z Hyogo 2005-2015.

${ }^{19}$ Disaster Risk Reduction in the United Nations. Rules, mandates and results of key UN entities, The United Nation Office for Disaster Risk Reduction, 2013, dostęp online $<$ http://www. unisdr.org/files/32918_drrintheun2013.pdf>, (12.07.2015) 
katastrofami a konfliktami i sformułowano wniosek, że ryzyko związane z degradacją środowiska, katastrofami naturalnymi, bezpieczeństwem żywnościowym, finansową niestabilnością a konfliktami wewnątrz- i międzypaństwowymi współgenerują się wzajemnie w ramach skomplikowanej sieci oddziaływań na poziomach globalnym i regionalnym. Od 2005 r. UNDP prowadząc współpracę z rządami państw, społecznościami i innymi partnerami koncentruje się na wzmacnianiu systemów instytucjonalnych oraz mechanizmów prawnych i politycznych dotyczących uregulowania redukcji i zarządzania ryzykiem katastrof, a także udziela wsparcia tym działaniom, które przyniosły efektywne rozwiązania i ułatwienia w ich wdrażaniu. Ponadto w celu uzyskania większej skuteczności radzenia sobie z ryzykiem katastrof wpierany jest rozwój wertykalnych i horyzontalnych interakcji między aktorami stosunków międzynarodowych, a także polityki i zasad finansowania, które umożliwiłyby zbudowanie systemowych powiązań i ról w zarządzaniu tego rodzaju ryzykiem. ${ }^{20}$

W tzw. Programie Strategicznym UNDP 2014-2017 organizacja promuje koncepcję disaster risk governance, którą określa jako ,sposób kooperacji władz państwowych, urzędników, mediów, sektora prywatnego, społeczeństwa obywatelskiego na poziomie lokalnym, narodowym i regionalnym w celu zarządzania (management) i redukcji katastrof i ryzyka związanego ze zmianami klimatu". ${ }^{21}$ Elementem tej koncepcji pozostaje disaster risk management, definiowany jako systematyczny proces stosowania regulacji administracyjnych oraz zdolności operacyjnych organizacji w realizacji strategii i podnoszenia efektywności radzenia sobie i zmniejszania negatywnych skutków prawdopodobnych zagrożeń i katastrof. ${ }^{22}$ Wśród państw, które są największymi beneficjentami pomocy ze strony UNDP występują m.in. Ekwador, Kolumbia, Kuba, Meksyk, Ghana, Mozambik, Uganda, Armenia, Kirgistan, Indonezja, Wietnam, Wyspy Salomona, Vanuatu, Dżibuti. Określenie poziomu zagrożenia wystąpienia katastrof naturalnych dla poszczególnych państw uruchamia określone mechanizmy decyzyjne powstające w wyniku oddziaływań między narażonym państwem a organizacją międzynarodową (nie tylko UNDP) oraz między państwami na poziomie regionalnym. Biorąc pod uwagę ewolucję celów stawianych sobie przez ONZ na kolejne lata można zauważyć, że w tzw. post-2015 priorytetach działalności, (a więc po zakończeniu realizacji Celów Milenijnych ONZ), zjawiska rosnącego ryzyka katastrof naturalnych oraz ich skutków społecznych i środowiskowych będą kluczowymi problemami działalności Organizacji Narodów Zjednoczonych i większości jej agend wyspecjalizowanych. Wydaje się, że obecnie i w przyszłości aktywność

${ }^{20}$ Strengthening Disaster Risk Governance: UNDP Support during the HFA Implementation Period 2005-2015, UNDP publication, dostęp online <http://www.undp.org/content/dam/undp/library/crisis\%20prevention/disaster/Strengthening\%20Disaster\%20Risk\%20Governance-Full-Report.pdf $>,(10.07 .2015)$.

${ }^{21}$ Ibidem, s. 8.

${ }^{22}$ UNISDR Terminology on Disaster Risk Reduction, UNISDR, Genewa 2009, s. 36. 
skoncentruje się na analizach tego ryzyka i zarządzaniu nim na poziomie międzynarodowym i dążeniu do urzeczywistnienie koncepcji disaster risk governance.

Światowe Forum Ekonomiczne (WEF) również opracowuje raporty dotyczące ryzyka globalnego (od 2005 r.), które ujmują go wielopłaszczyznowo i uwzględniają dużo szerszy zakres tego pojęcia niż ONZ. Raporty są sporządzanie na podstawie wywiadów przeprowadzanych wśród różnych grup respondentów (biznesmeni, politycy, przywódcy państw, główni przedstawiciele organizacji międzynarodowych i poza-rządowych, a także specjaliści oraz naukowcy), najczęściej podczas spotkań na forum WFE przez rok poprzedzający jego wydanie. W badaniach uwzględnione są dwie kategorie: aktualne trendy światowe i związane z nimi ryzyko. Są one sklasyfikowane w czterech płaszczyznach: ekonomicznej społecznej, geopolitycznej, technologicznej i środowiska naturalnego i zestawione według poziomu prawdopodobieństwa zaistnienia oraz poziomu oddziaływania (impact). ${ }^{23}$ Wykorzystywane jest pojęcie tzw. ryzyka systemowego ze względu na współzależności między tymi płaszczyznami i wzajemne warunkowanie się ryzyka. Jak pokazuje poniższa tabela, każdej płaszczyźnie przypisane są określone zjawiska stanowiące źródła ryzyka. Istotne jest to, że wszystkie z nich mają szeroki zakres oddziaływania, wychodzący poza obszary dotknięte tymi zjawiskami, a kilka z nich (wszystkie z płaszczyzny ekonomicznej, kilka z politycznej oraz wybuchy pandemii) wskazuje na wysoką współzależność elementów całego systemu wywołując zjawisko ryzyka na poziomie globalnym.

Tab. 1. Zestawienie 31 rodzajów ryzyka w 5 kategoriach wg. Światowego Forum Ekonomicznego

\begin{tabular}{|c|c|}
\hline $\begin{array}{c}\text { Kategoria } \\
\text { Ryzyka }\end{array}$ & Rodzaje ryzyka \\
\hline \multirow{7}{*}{$\begin{array}{l}\overleftarrow{Z} \\
0 \\
0 \\
0 \\
0 \\
0 \\
0 \\
0 \\
=1\end{array}$} & Kryzysy finansowe dużych gospodarek światowych \\
\hline & Załamanie się istotnych mechanizmów i instytucji finansowych \\
\hline & Kryzysy utrzymania płynności \\
\hline & Wysoki poziom bezrobocia/nadmiernego zatrudnienia strukturalnego \\
\hline & Wysokie wahania cen ropy naftowej \\
\hline & Upadek lub deficyt infrastruktury krytycznej \\
\hline & Spadek znaczenia dolara amerykańskiego jako waluty międzynarodowej \\
\hline \multirow{6}{*}{ 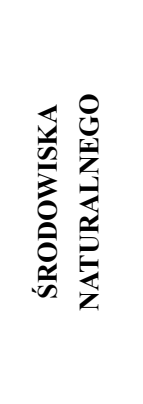 } & Wzrost ekstremalnych zjawisk pogodowych (np. powodzie, huragany, susze) \\
\hline & $\begin{array}{l}\text { Wzrost liczby katastrof naturalnych (np. trzęsienia ziemi, wybuchy wulkanów, tsu- } \\
\text { nami, burz geomagnetycznych) }\end{array}$ \\
\hline & $\begin{array}{l}\text { Wzrost liczby katastrof ekologicznych wywołanych działalnością człowieka (np. } \\
\text { wycieki ropy do mórz, wypadki/awarie w elektrowniach atomowych) }\end{array}$ \\
\hline & $\begin{array}{l}\text { Pogłębianie się zjawiska utraty bioróżnorodności i zachwiania ekosystemu (na zie- } \\
\text { mi i w oceanach) }\end{array}$ \\
\hline & Deficyt wody pitnej \\
\hline & $\begin{array}{l}\text { Zahamowanie procesów łagodzenia i adaptacji środowiska wobec zmian klimatycz- } \\
\text { nych }\end{array}$ \\
\hline
\end{tabular}

${ }^{23}$ Word Economic Forum, Global Risks Reports 2015, http://report.weforum.org/global-risk2015/, (2.07.2015). 


\begin{tabular}{|c|c|}
\hline \multirow{8}{*}{ 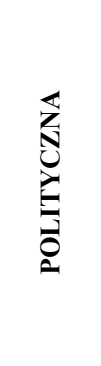 } & Upadek global governance \\
\hline & Problemy państw o istotnym znaczeniu geopolitycznym \\
\hline & Wzrost poziomu korupcji \\
\hline & Znaczna eskalacja zorganizowanej przestępczości i nielegalnego handlu \\
\hline & Ataki terrorystyczne na dużą skalę \\
\hline & Proliferacja broni masowego rażenia \\
\hline & $\begin{array}{l}\text { Ostre konflikty między państwami o istotnych konsekwencjach na poziomie regio- } \\
\text { nów }\end{array}$ \\
\hline & Wzrost procesów nacjonalizacji gospodarek i zasobów naturalnych \\
\hline \multirow{7}{*}{ 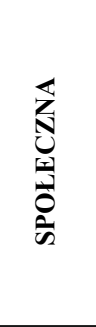 } & Kryzysy żywnościowe \\
\hline & Wybuchy pandemii \\
\hline & Trudne do opanowania choroby chroniczne \\
\hline & Wysokie dysproporcje w dochodach \\
\hline & Występowanie szczepów bakterii antybiotykoopornych \\
\hline & $\begin{array}{l}\text { Niewłaściwa urbanizacja obszarów (zaniechanie planów lub budowa niewłaściwej } \\
\text { infrastruktury i łańcucha dostaw) }\end{array}$ \\
\hline & Głęboka niestabilność polityczna i społeczna \\
\hline \multirow{3}{*}{ 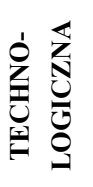 } & Uszkodzenia krytycznej infrastruktury informatycznej i sieciowej \\
\hline & Wzrost cyber-ataków na dużym zasięgu \\
\hline & Masowe zjawiska kradzieży i oszustwa danych \\
\hline
\end{tabular}

Źródło: Word Economic Forum, Global Risks Report 2014, s. 6.

Liczba źródeł ryzyka w poszczególnych kategoriach nie jest jednakowa i póki co, na płaszczyźnie technologicznej jest ich najmniej. Wydaje się jednak, że czynnikiem determinującym jest tu czas. Zjawiska związane z ryzykiem na płaszczyznach politycznej ekonomicznej, społecznej i środowiska naturalnego pojawiały się już wielokrotnie w historii człowieka i tym samym są lepiej poznane, a mechanizmy radzenia sobie z nimi bardziej zróżnicowane. Inaczej jest w przypadku technologii, które nadal (jeszcze) pozostają pod kontrolą człowieka, ale mogą być wykorzystane $\mathrm{w}$ różny sposób. $\mathrm{Z}$ drugiej strony skutki zjawisk ryzykownych w pierwszych trzech płaszczyznach są bardziej spektakularne i generują obecnie wyższe straty społeczne i ekonomiczne niż ryzyko pochodzenia technologicznego. Jednak jak twierdził U. Beck, skutki modernizacji i rewolucji technologicznej są dużo trudniejsze do ustalenia.

W Raporcie sporządzono również ranking rodzajów ryzyka według dwóch podstawowych parametrów jego mierzenia: poziomu prawdopodobieństwa zaistnienia i skali wpływu na dany system ${ }^{24}$ (tabela 2 ).

${ }^{24}$ Parametrem, który jest również uwzględniany w innych metodologiach badania ryzyka jest wrażliwość systemu na dane zjawisko, który determinuje w dużej mierze skutki i proces wychodzenia $z$ danej sytuacji. 
Tab. 2. Dziesięć rodzajów ryzyka globalnego wg. skali poziomu prawdopodobieństwa i wpływu w 2015 r. (od najwyższej do najniższej)

\begin{tabular}{|c|l|l|}
\hline rank & Ryzyko wg skali prawdopodobieństwa & \multicolumn{1}{c|}{ Ryzyko wg skali wplywu } \\
\hline 1 & Konflikty międzypaństwowe & Deficyty wody pitnej \\
\hline 2 & Ekstremalne zjawiska pogodowe & Rozprzestrzenianie się chorób infekcyjnych \\
\hline 3 & Destabilizacje wewnątrz państw & Produkcja broni masowego rażenia \\
\hline 4 & $\begin{array}{l}\text { Upadające i dotknięte strukturalnymi } \\
\text { kryzysami państwa }\end{array}$ & Konflikty między państwami \\
\hline 5 & $\begin{array}{l}\text { Bezrobocie lub nadmierny poziom } \\
\text { zatrudnienia }\end{array}$ & $\begin{array}{l}\text { Zahamowanie procesów adaptacji } \\
\text { środowiska naturalnego wobec zmian } \\
\text { klimatycznych }\end{array}$ \\
\hline 6 & Katastrofy naturalne & Szoki cenowe energii \\
\hline 7 & $\begin{array}{l}\text { Zahamowanie procesów adaptacji } \\
\text { śodowiska naturalnego wobec zmian } \\
\text { klimatycznych }\end{array}$ & $\begin{array}{l}\text { Upadek krytycznej infrastruktury } \\
\text { informacyjnej }\end{array}$ \\
\hline 8 & Deficyty wody pitnej & Kryzysy państwa podatkowego \\
\hline 9 & Kradzież i oszustwa danych & $\begin{array}{l}\text { Bezrobocie lub nadmierny poziom } \\
\text { zatrudnienia }\end{array}$ \\
\hline 10 & Cyber-ataki & $\begin{array}{l}\text { Utrata bioróżnorodności środowiska } \\
\text { naturalnego i upadek ekosystemu }\end{array}$ \\
\hline
\end{tabular}

Źródło: World Economic Forum, Global Risk Analysis Report 2015.

Wśród dziesiątki najbardziej prawdopodobnych rodzajów ryzyka najwięcej jest tych dotyczących występowania potencjalnych zagrożeń pochodzenia naturalnego. W Raporcie podkreślono, że w latach 2007 - 2014 zjawiska te wyparły w znacznym stopniu ryzyko pochodzenia ekonomicznego, które dominowało we wcześniejszym okresie. ${ }^{26}$ Jest to konsekwencja zmian klimatu i wzrostu liczby katastrof naturalnych na świecie. Istotne jest również umieszczenie problemu deficytu wody pitnej jako zjawiska mającego największy wpływ na system. Można przewidzieć, że jego efektem będzie wzrost procesów migracyjnych, konfliktów międzypaństwowych oraz cen na wodę pitną. Konflikt geopolityczny między Rosją i Ukrainą, wojna domowa w Syrii aktywizująca państwa sąsiednie do działań ofensywnych, nawracające konflikty w strefie Gazy, wewnętrzne walki w Libii, Sudanie Południowym czy Nigerii, a także idea powstania państwa islamskiego uznano za zjawiska o dużym wpływie na system międzynarodowy.

W Raporcie WEF, dla poszczególnych regionów na świecie określono rodzaje ryzyka do których są one najmniej przygotowane. Można uznać to za wskaźnik największej wrażliwości tych obszarów na określone ryzyka. I tak dla Europy są to

${ }^{25}$ Zjawisko kryzysu państwa podatkowego została opracowana przez J. A. Schumpetera i dotyczy nadmiernego rozwoju sektora publicznego oraz obciążenia podatkami, które wpływają na zahamowanie rozwoju gospodarczego i zachwianie mechanizmów rynkowych. Szerzej: A. Glapiński, Teoria kryzysu państwa podatków J. A. Schumpetera, „Ekonomista” nr 1, 2003, s. 21-40.

${ }^{26}$ Global Risks Reports 2015, op. cit. 
strukturalne bezrobocie i nadwyżki w zatrudnieniu oraz mimowolna migracja na dużą skalę generujące razem głęboką niestabilność społeczną. Ameryka Północna wykazuje wysoką wrażliwość na niedobór infrastruktury krytycznej, cyber-ataki na wielką skalę oraz utratę zdolności adaptacyjnych środowiska wobec zmian klimatycznych. Dotychczasowe wydarzenia na tym kontynencie wskazują na istotny brak przygotowania na ostatni typ ryzyka. Kolejno uznano, że Afryka Subsaharyjska jest najmniej przygotowana na choroby infekcyjne i bezrobocie. Przejawy ich były już widoczne w ostatnich latach (m.in. wirus Ebola), natomiast stały wzrost liczby ludności będzie nasilał te zjawiska. Region Azji Wschodniej i Pacyfiku wg Raportu Ryzyka WEF jest najbardziej wrażliwy na konflikty międzypaństwowe i uszkodzenie infrastruktury miejskiej. Jest to jedyny region, który po katastrofie elektrowni atomowej w Fukishimie w 2011 r. sam wydał raport stwierdzający niewystarczające przygotowanie do katastrof wywołanych działalnością człowieka. Ponadto region ten, podobnie jak Azja Południowa oraz Ameryka Łacińska i Karaiby są najbardziej wrażliwe na niepowodzenia w planowaniu przestrzennym, które w konsekwencji mogą prowadzić do niepokojów społecznych i wybuchów pandemii. ${ }^{27}$ Zgodnie z teorią ryzyka nie ma sytuacji „zero-ryzykownej” i wszystkie regiony mają swoje „słabe punkty”. Dostarczanie takich informacji jest kluczowe w procesie zarządzania ryzykiem, którego celem jest zwiększenie zdolności systemu do zapobiegania, przygotowania i reagowania na potencjalne zagrożenia. Biorąc jednak pod uwagę wysoką dyspersyjność większości analizowanych rodzajów ryzyka przez Światowe Forum Ekonomiczne, informacje zawarte w Raporcie powinny skłaniać państwa do budowania modeli zarządzania ryzykiem na poziomie regionalnym i międzynarodowym, by w efekcie synergii zwiększyć zdolności kontrolowania go.

W następujących po sobie raportach WEF coraz częściej wskazuje się na rosnącą niestabilność wielobiegunowego systemu międzynarodowego, który dodatkowo zwiększa prawdopodobieństwo wystąpienia ryzyka o zasięgu globalnym w niedoprecyzowanej czasowo przyszłości. Istnieje wysokie prawdopodobieństwo, że wywoła to przyjęcie dwóch przeciwstawnych strategii działania przez podmioty stosunków międzynarodowych, a szczególnie państw. Z jednej strony globalny zakres ryzyka będzie zmuszał je do podjęcia współpracy w celu efektywniejszego zarządzania nim, z drugiej strony do zachowań protekcjonistycznych, hamujących procesy globalizacji i tym samym współzależności.

Również Organizacja Współpracy Gospodarczej i Rozwoju (OECD) w swoich analizach i raportach coraz więcej miejsca poświęca występowaniu ryzyka różnego rodzaju, mającego wpływ na funkcjonowanie społeczeństwa i gospodarki światowej. W 2003 r., w obliczu wydarzeń z 11 września w USA, wystąpienia choroby BSE u krów w Europie, czy wirusa Ebola i jego rozprzestrzeniania się oraz katastrof

${ }^{27}$ Global Risks Perception Survey 2014, Word Economic Forum, dostęp online < http://reports.weforum.org/global-risks-2015/part-1-global-risks-2015/preparedness-at-the-regional-level-is-different/>, (10.07.2015). 
pochodzenia naturalnego $\mathrm{w}$ wielu regionach świata, wydała publikację „Emerging Risks in the 21st Century. An Agenda for Action". ${ }^{28}$ Wyróżniono tam pięć klastrów ryzyka: katastrofy naturalne, wypadki technologiczne, choroby infekcyjne, bezpieczeństwo żywności i terroryzm. Jak założono, celem publikacji było określenie nowych wyzwań, wobec których stanęły państwa OECD i sposobów reagowania na nie. Podobnie jak w raportach Światowego Forum Ekonomicznego stosowane jest pojęcie ryzyka systemowego. W rozumieniu OECD jest to rodzaj ryzyka, który ma niekorzystny wpływ na systemy, od których uzależnione jest społeczeństwo czyli systemy zdrowia, transportowe, telekomunikacyjne, środowiska naturalnego itp. ${ }^{29}$ W publikacji zwraca się uwagę na dwa problemy: zmianę natury ryzyka, które pojawiło się na początku XXI wieku oraz problemy związane z możliwością zarządzania nim (management). Wśród zjawisk generujących pojawianie się różnych rodzajów ryzyka w przyszłości wymieniono: 1) wzrost liczby ludności o 50\% w przeciągu kolejnych pięćdziesięciu lat oraz starzenie się społeczeństwa; 2) ocieplanie się klimatu pociągające za sobą ekstremalne zjawiska pogodowe, spadek rezerw wody pitnej i bioróżnorodności; 3) wzrost tempa rozwoju technologicznego nie zawsze uwzględniający wszystkie jego konsekwencje i mogący prowadzić do głębokich zmian sposobów życia człowieka; 4) dysproporcje w dochodach wewnątrz i między państwami, które nie ulegną znaczącej zmianie, 5) pojawienie się większej liczby państw, w których w wyniku prywatyzacji i deregulacji znaczącą rolę w procesie decyzyjnym będą odgrywały organizacje pozarządowe i międzynarodowe, a media będą kształtowały opinię publiczną wpływając na zmianę koncepcji rządzenia państwem. Wobec tych zjawisk OECD przewidziało wystąpienie pięciu istotnych problemów z zarząadzaniem ryzykiem w przyszłości oraz sformułowało swoje rekomendacje. Należą do nich: 1) wzrost złożoności ryzyka jako przedmiotu oddziaływań rosnącej liczby czynników, zalecenie - stworzenia nowych instrumentów i podejść w zarządzaniu ryzykiem; 2) koncentracja i zwiększenie skali agregacji ryzyka, zalecenie - adaptacja różnych elementów zarządzania ryzykiem, od systemów ostrzegawczych do programów ubezpieczeniowych, wobec wzrostu prawdopodobieństwa wystąpienia w przyszłości klęsk na wielką skalę; 3) nieadekwatność dotychczasowych metod zarządzania ryzykiem do jego skali i heterogeniczności, rekomendacja - rozwój badań i konsultacji naukowych mających wypracować stosowne modele zarządzania; 4) zmiany ról i odpowiedzialności w zarządzaniu ryzykiem, rekomendacja - określenie podmiotów odpowiedzialnych za bezpieczeństwo w poszczególnych sektorach oraz wprowadzenie nowych i zróżnicowanych instrumentów działania, np odpowiedzialności deliktowej; 5) brak koherencji między formalnymi metodami zarządzania ryzykiem a postrzeganiem tego ryzyka przez społeczeństwo dotknięte zjawiskami ekstremalnymi, wpływ mediów na reakcje społeczne, rekomendacja - analizy percepcji i sposobów radzenia sobie przez

${ }^{28}$ Emerging Risks In the 21st Century. An Agenda for Action, Organisation for Economic Co-operation and Development, 2003.

${ }^{29}$ Op. cit., s. 30. 
ludzi z występowaniem określonych katastrof czy wypadków oraz zabezpieczania się przed nimi ${ }^{30}$ Ponadto Organizacja promuje tworzenie współodpowiedzialności sektora publicznego i prywatnego w zapobieganiu zjawisk niosących wysokie straty społeczno-ekonomiczne oraz pobudzanie efektu synergii w wyniku ich współpracy w dziedzinie zarządzania kryzysów i katastrof na dużą skalę. ${ }^{31}$

Wśród wielu raportów sporządzanych przez OECD coraz więcej poświęconych jest kategorii ryzyka w ujęciu wielopłaszczyznowym. Organizacja opracowuje rekomendacje m.in. dla sektora biznesowego, (korporacji) określające ich działania na rynku, które mogą wpływać na zwiększanie prawdopodobieństwa i zakresu oddziaływania ryzyka. Widoczna jest także współpraca między różnymi organizacjami międzynarodowymi wspierającymi inicjatywy na rzecz ograniczania ryzyka. W 2007 r., po wydaniu przez EOCD przewodnika zatytułowanego Risk Awareness Tool for Multinational Enterprises In Weak Governance Zones, skierowanego do korporacji wielonarodowych, Rada Bezpieczeństwa ONZ podkreśliła znaczenie tej Organizacji w promowaniu odpowiedzialnego biznesu i działań na rzecz zaniechania nielegalnej eksploatacji zasobów naturalnych w państwach dotkniętych konfliktami. Podobnie grupa G8 w „Deklaracji z Heiligendemm o Rozwoju i Odpowiedzialności w Gospodarce Światowej” również wsparła zawarte $\mathrm{w}$ tej publikacji zalecenia i zobowiązała się do wspierania szerszego rozumienia działalności wydobywczej w oparciu o nie. ${ }^{32}$

Z przedstawionych powyżej obszarów zainteresowania i działalności znaczących w świecie organizacji międzynarodowych wynika, że kategoria ryzyka staje się po pierwsze instrumentem analizy zjawisk występujących we współczesnym środowisku międzynarodowym, metodą radzenia sobie $\mathrm{z}$ wysoko prawdopodobnymi zagrożeniami, pozwalającą na wypracowanie mechanizmów adaptacji antycypacyjnej. Zauważalna jest spójność między zjawiskami zaliczanymi do kategorii ryzyka przez przedstawione organizacje pod względem czynników napędzających pojawienie ryzyka oraz komplementarność w wypracowaniu rekomendacji zarządzania nim.

\section{ZAKOŃCZENIE}

Powyższe rozważania wskazują na coraz szersze zainteresowanie kategorią ryzyka w badaniu zjawisk pociągających za sobą negatywne skutki o szerokim zakresie terytorialnym i wpływie oraz w kształtowaniu relacji między podmiotami stosunków międzynarodowych. Wydaje się jednak, że rozwinięta metodologicznie teoria ryzyka w innych naukach nadal jest zbyt rzadko wykorzystywana

${ }^{30}$ Op. cit., s. 54.

${ }^{31}$ Op. cit., s. 24.

32 Risk Awareness Tool for Multinational Enterprises In Weak Governance Zones, OECD 2006, dostęp online $<$ http://www.oecd.org/daf/inv/corporateresponsibility/36885821.pdf>, (20.07.2015). 
w dziedzinie stosunków międzynarodowych. Coroczne indeksy ryzyka tworzone przez organizacje międzynarodowe czy grupy eksperckie są źródłem informacji pozwalającym po pierwsze na zapoznanie się z rodzajem i cechami współczesnych prawdopodobnych zagrożeń (także trendów ryzykogennych) i po drugie na przestudiowanie instrumentów, które podmioty wykorzystują w działaniach wobec tych zjawisk, a tym samym oddziaływaniach na państwa. Ponadto pojedyncze rodzaje ryzyka mogą stanowić podstawę do głębszej analizy wybranych płaszczyzn stosunków międzynarodowych z wykorzystaniem metod statystycznych i probabilistycznych. Dane te są również źródłem wiedzy o cechach współczesnego środowiska międzynarodowego, które kreują i będą kreowały w coraz większym stopniu relacje między państwami i z innymi aktorami.

Współpraca państw w dziedzinie zarządzania ryzykiem daje możliwość korzystania z doświadczeń innych i/lub zapożyczenia pomysłów politycznych w procesie transnarodowego rozprzestrzeniania innowacji regulacyjnych. Natomiast transgraniczność skutków ryzyka pozwala na rozłożenie kosztów działań operacyjnych między wieloma podmiotami stosunków międzynarodowych. Występowanie współzależności na świecie, szczególnie ekonomicznych, wpływa na udział większej liczby aktorów w stratach finansowych niż tylko tych bezpośrednio dotkniętych jakimś kataklizmem. Stąd w interesie „,teoretycznie nie zagrożonych bezpośrednio" państw jest przewidywanie i możliwe zabezpieczenie ryzyka poniesienia strat w wyniku zagrożeń egzogennych. Współzależność geopolityki i ekonomii w obszarze globalnego ryzyka, może rozwijać nowe i zmieniać charakter dotychczasowych powiązań między podmiotami tworząc dodatkowe obszary współpracy międzynarodowej.

Rozwój wiedzy i metod badawczych ryzyka pozwala w jakimś stopniu wpływać na prawdopodobne zagrożenia w celu minimalizowania ich skutków negatywnych. Z jednej strony wymaga to wiedzy specjalistycznej, którą można wykorzystać do analizy ryzyka pojedynczych zjawisk (np. skutków cyber-terroryzmu), a z drugiej podejścia holistycznego, które pozwoli na uzyskanie nowej wiedzy naukowej dotyczącej sposobów, w jakich ryzyko kształtuje stosunki międzynarodowe i w jakich podmioty tych stosunków kreują ryzyko.

\title{
RISKS AS A CATEGORY OF ANALYSIS OF CONTEMPORARY IR
}

\begin{abstract}
The theme of the article is "risk" considered as a category of research - with a widely developed methodological base-and its application to the analysis of contemporary international relations. Various proposals of scientists in different sciences for defining risk are presented. Moreover, reports concerning risk by selected international organisations are included. These reports indicate the important role of risk as a feature of the contemporary international environment and they are a great source of information for researchers of international relations.
\end{abstract}

Key words: risk, international cooperation in risk management, risk analysis, reports on risk. 